\title{
Awareness of narrative identity and selected aspects of narrative activity and meaning-making. Preliminary results
}

\author{
Kamil Janowicz ${ }^{1}$ \\ Adam Mickiewicz University in Poznań, Faculty of Psychology and Cognitive Science \\ Emilia Soroko \\ Adam Mickiewicz University in Poznań, Faculty of Psychology and Cognitive Science \\ David J. Hallford \\ Deakin University, School of Psychology
}

\begin{abstract}
Narrative identity allows us to integrate various experiences and incorporate them into the concept of the self. Recent studies indicate that being aware of developing the story about the self that brings cohesion and meaning may be adaptive. This paper presents preliminary findings across three studies (two quantitative and one mixed methods) aimed at exploring the phenomenon of awareness of narrative identity in terms of its relations to other aspects of narrative identity and meaning-making (meaning in life, self-esteem, and post-traumatic growth). The total number of participants in all studies was $840\left(\mathrm{~N}_{1}=254 ; \mathrm{N}_{2}=424 ; \mathrm{N}_{3}=162\right)$. Results indicate that stronger awareness of narrative identity is related to higher self-narrative inclination and reflexivity, and may be adaptive in terms of meaningmaking and coping with traumatic events. People that were more aware of a narrative identity produced more elaborated and coherent self-narrations about an important past relationship. What is more, they had a stronger tendency to integrate these past experiences with a sense of self identity. Surprisingly, awareness of narrative identity was not related to self-esteem. These findings have been discussed referring in terms of narrative identity literature. Moreover, possible directions for further studies to expand our understanding of awareness of narrative identity are proposed.
\end{abstract}

Key words: narrative identity, narrative activity, meaning-making, narrative psychology, narrative coherence, post-traumatic growth

\footnotetext{
${ }^{1}$ Corresponding author: kamil.janowicz@amu.edu.pl
} 


\section{INTRODUCTION}

Narrative identity is an internalized and evolving story that we create about the self, based on personal autobiographical memories. It is thought to contribute to a sense of purpose, meaning, and unity across time and situation (Adler, 2012; McAdams, \& McLean, 2013). One of the most important adaptive functions of a narrative identity is to meaningfully integrate positive and negative, congruent and contradictory experiences. Even where new experiences were challenging, they can become meaningful and assimilate into self. A process of autobiographical reasoning brings the sense of understanding of self and others (McLean, \& Pratt, 2006; Pasupathi, \& Mansour, 2006; Singer, \& Bluck, 2001). Studies have shown there is a relationship between narrative identity and psychological well-being and mental health, especially in an existential aspect related to sense of purpose and continuity of life (e.g., McAdams 2001, 2006). Sense of personal integration is often linked to the global coherence of a life story, which itself is related to psychological well-being and self-esteem (Chen et al., 2012; Hallford, Ricarte, \& Hermans, 2021; McLean, \& Breen, 2009; Mitchell et al., 2009; McLean et al., 2010).

Recent research on narrative identity has highlighted the metacognitive ability of awareness of narrative identity, which refers to 'understanding that one's experiences might be represented as a story about self that informs about one's identity' (Hallford, \& Mellor, 2015, p. 2). Hallford and Mellor (2015) suggested, and evidenced, that being aware of developing the story about self that bring cohesion and meaning may be adaptive itself and related to lower depressive symptoms and higher meaning in life, self-esteem, and self-efficacy. What is more, they showed that people who are more aware about developing a narrative identity tend to provide more coherent narratives about turning-point events. These results have been replicated by Sevim and Otrar (2021) in terms of meaning in life, self-esteem, and self-efficacy, and studies have shown that changes in awareness of narrative identity occur as part of adaptive reminiscence interventions (Hallford \& Mellor, 2016; Hallford et al., 2021b).

The aforementioned findings are in line with Habermas and Köber (2015) research indicating that mere remembering of past episodes is not sufficient to preserve a sense of identity continuity. Accordingly, it seems that conscious factors (e.g., effort involve autobiographical reasoning) are engaged when forming a sense of life cohesion in situations of crucial life changes (see Blagov et al., 2013; Oleś, 2004). The phenomenon of awareness of narrative identity seems to be a promising construct, which may be adopted to studies on narrative identity. Therefore, in addition to replicating findings about its potential role for meaning in life, self-esteem, and mental health, it is necessary to examine its relation to other 
aspects of narrative identity. Against this background, we present three independent studies with interrelated aims:

1. To replicate Hallford and Mellor's (2015) study on the associations between awareness of narrative identity, thinking and talking about life, and psychological resources including meaning in life, self-esteem, expecting a pattern of positive correlations (Study 1).

2. To verify the hypothesis of positive correlations between awareness of narrative identity and the level of coherence in written autobiographical narratives (Study 1), and to also examine self-narrative inclination and the self-relevance of narratives. These latter two constructs are not yet studied in this context. Self-narrative inclination is the tendency or need of a person to take a third-party perspective on one's life and speculate about events involving oneself and express his/her own experiences in the form of a story in which the narrator is a protagonist (Soroko, 2013). An essential feature of self-narrative inclination is its identity-forming aspect, expressed in looking at one's life from a distance and treating it as a story (e.g., Suchańska \& Ligocka, 2011). Self-relevance relates to the ability to perceive experiences as being related to insights or learning about oneself and, in the case of specific written narratives, might indicate the process of integrating stories into one's global sense of self. Therefore, we expected that the global awareness of narrative identity (especially in the dimension of thematic coherence) would be positively related to objectively coded dimensions of narrative coherence in specific written narratives, as well as higher self-narrative inclination, and self-relevance.

3. To further assess the adaptive role of narrative identity awareness identified by Hallford and Mellor (2015) by assessing its association with rumination and reflexivity (Study 1, Study 2, Study 3) and post-traumatic growth (Study 3). In the case of rumination, a negative correlation is predicted given that the tendency to think of negative past experiences and related feelings unproductively and repetitively might reflect difficulty with resolving these experiences and forming coherent, integrated stories about the self. Conversely, reflection involving remembering past experiences to gain insight and perspective is expected to be positive correlated with awareness of narrative identity. In the case of post-traumatic growth, a positive correlation is predicted given that changes in self-concept that occur following traumatic experiences may benefit from awareness of stories integrating themes of loss, threat, growth etc. 


\section{Study 1 - Awareness of Narrative Identity, Psychological Resources and Narrative Coherence, Inclination and Self-Relevance}

\section{Materials and methods}

\section{Participants and procedure}

The study included 254 participants (see Table 1 for demographic details) who gave informed consent for this non-remunerated scientific study. The questionnaires were completed by paper and pencil (30\%) and online (70\%), which did not differ in terms of gender $\left(\chi^{2}=.02\right.$; $p=.877)$, age $(t=-.98 ; p=.326)$, education $\left(\chi^{2}=10.9 ; p=.090\right)$ or marital status $\left(\chi^{2}=4.3 ; p\right.$ $=.363$ ). The group filling in the paper version was reached by means of the snowball method (participants were invited during classes at university, and interpersonal networks were leveraged), and the Internet sample was reached by means of open announcements on forums, where students of scientific groups were encouraging to participate. A smaller subsample $(n=$ 71; see Table 1 for demographic details) was asked to complete the narrative task including writing an autobiographical and personally meaningful story about a relationship with a significant person.

Table 1.

Participants' Demographics (Study 1a, 1b, 2, 3).

\begin{tabular}{|c|c|c|c|c|c|c|c|c|c|}
\hline \multirow[b]{2}{*}{ Variable } & & \multicolumn{2}{|c|}{ Study 1a } & \multicolumn{2}{|c|}{ Study 1b } & \multicolumn{2}{|c|}{ Study 2} & \multicolumn{2}{|c|}{ Study 3} \\
\hline & & $\mathrm{N}$ & $\%$ & $\mathrm{~N}$ & $\%$ & $\mathrm{~N}$ & $\%$ & $\mathrm{~N}$ & $\%$ \\
\hline \multirow[t]{4}{*}{ Gender } & & 254 & - & 71 & - & 424 & - & 162 & - \\
\hline & Female & 198 & 74.0 & 53 & 74.6 & 321 & 76.0 & 98 & 60.0 \\
\hline & Male & 56 & 26.0 & 18 & 25.3 & 103 & 24.0 & 63 & 38.9 \\
\hline & Other & 0 & 0.0 & 0 & 0.0 & 0 & 0.0 & 1 & 0.6 \\
\hline Age: mea & $\begin{array}{l}\text { SD), min- } \\
\max \end{array}$ & $29(1$ & $17-81$ & 28.01 & , 19-81 & 24.60 & ), $18-45$ & 28.77 & $18-67$ \\
\hline
\end{tabular}

Education:

$\begin{array}{rcccccccc}\text { Primary } & 0 & 0.0 & 0 & 0.0 & 3 & 0.7 & 5 & 3.1 \\ \text { Vocational } & 0 & 0.0 & 0 & 0.0 & 0 & 0.0 & 4 & 2.5 \\ \text { Secondary } & 97 & 38.3 & 34 & 48.5 & 204 & 48.1 & 55 & 34.0 \\ \text { Higher } & 157 & 61.3 & 36 & 51.4 & 217 & 51.2 & 98 & 60.5 \\ \text { NA } & 2 & 0.4 & 0 & 0.0 & 0 & 0.0 & 0 & 0.0\end{array}$


Marital status:

$\begin{array}{rcccccccc}\text { Single } & 87 & 34.4 & 49 & 69.0 & 148 & 34.9 & \\ \begin{array}{r}\text { Partnered but not } \\ \text { cohabitating }\end{array} & 66 & 25.9 & 0 & 0.0 & 90 & 21.2 & \\ \text { Married } & 55 & 21.7 & 12 & 16.90 & 54 & 12.7 & & \\ \begin{array}{r}\text { Partnered and } \\ \text { cohabitating }\end{array} & 42 & 16.5 & 10 & 14.1 & 74 & 15.5 & \text { NA } & \text { NA } \\ \text { Divorced } & 2 & 8.0 & 0 & 0.0 & 4 & 0.9 & & \\ \text { Separated } & 2 & 8.0 & 0 & 0.0 & \text { NA } & \text { NA } & \\ \text { Engaged } & \text { NA } & \text { NA } & \text { NA } & \text { NA } & 48 & 11.3 & \\ \text { Widowed } & \text { NA } & \text { NA } & \text { NA } & \text { NA } & 2 & 0.5 & \end{array}$

Place of residence:

Village

$\begin{array}{llll}68 & 16.0 & 19 & 11.0\end{array}$

City up to 50,000

52

12.3

$18 \quad 7.0$

City between 50,000

NA NA NA

NA

49

$11.6 \quad 35$

11.0

City between 200,000

and 500,000

255

60.1

90

55.6

City over 500,000

NA

NA

NA

NA

\section{Measures}

Awareness of Narrative Identity. The Awareness of Narrative Identity Questionnaire (ANIQ) (Hallford, \& Mellor, 2015; Polish adaptation [ANIQ-PL]: Soroko et al., 2019) is a 20-item selfreport questionnaire to assess awareness of narrative identity and the perception of how globally coherent one's autobiographical memories are in terms of temporal order, causal associations, and themes. The ANIQ is divided into four scales (each includes 5 items): awareness, temporal coherence, causal coherence, and thematic coherence. Participants responded on each item using 10-point end-defined scale ranging from 1 (I absolutely disagree) to 10 (I absolutely agree). Higher scores indicated: a) higher level of awareness that one has developed the stories about own life, b) being more conscious about drawing on these stories to understand the kind of person, c) perceiving personal autobiographical memories as more coherent in terms of temporal order, causal associations, and themes. The ANIQ-PL scales demonstrated high internal consistency levels in this sample $(\alpha=.87-.94)$. 
Meaning in Life. The Meaning in Life Questionnaire (MLQ) (Steger et al., 2006; polish adaptation: Kossakowska et al., 2013) measures the presence of meaning in life (MLQPresence) and search for meaning in life (MLQ-Search). Participants responded to 10 items using 7-point end-defined scale ranging from 1 (absolutely untrue) to 7 (absolutely true), with higher scores on this scale indicating a stronger sense of personal meaning in life or a stronger sense of searching for meaning. The internal consistency was good for the MLQ-P $(\alpha=.87)$ and MLQ-S $(\alpha=.81)$ subscales.

Self-esteem. The Self-esteem Scale (SES; Rosenberg, 1965; polish adaptation: Łaguna et al., 2007) includes 10 items rated on a 4-point end-defined scale ranging from 1 (I absolutely disagree) to 4 (I absolutely agree). SES is used to measure self-reported level of self-esteem as a relatively stable trait (Łaguna et al., 2007). Higher scores indicated higher self-esteem. The internal consistency was good in this sample $(\alpha=.92)$.

Self-narrative Inclination. The Self-Narrative Inclination Questionnaire (IAN-R; Soroko, 2013) encompasses self-narrative inclination as a three-dimensional construct: distancing from experience (inclination to take third-party perspective on one's life and speculate about events involving oneself, in particular about the impact of past events on the present; 13 items), selfnarrative recounting (inclination to recount autobiographical events in a convention of a story in which the narrator is a protagonist; 13 items), and making use of cultural heritage (inclination to make use of cultural heritage, like books, films, cultural patterns, when referring to one's own experiences; 4 items). Participants responded to 30 items using a 5-point lettered scale: A - I absolutely agree (5 points), a - I partially agree (4 pts.), ab - hard to say (3 pts.), b - I partially disagree (2 pts.), B - I absolutely disagree (1 pt.). Higher scores indicated stronger self-narrative inclination in regard to each aspect. Internal consistency for the IAN-R in this study was good (Cronbach's $\alpha=$ for subscale respectively: .89, .90, .79).

Frequency of talking and thinking about one's life. Two self-report items directly referring to talking ("In general, how often do you talk to others about what's happened in your life") and thinking (“In general, how often do you think back over your life?") about one's life. A scale ranging from 0 (never) to 10 (very often) was used (Hallford \& Mellor, 2015). Higher scores indicated more frequent thinking or talking about one's life.

Self-narrations and its features. Participants were asked to write about an important, emotional-engaging relationship. The instructions for participants were as follows: Please remind yourself and tell a story of any important interpersonal relationship, which has been engaging to you in an emotional way in the past. Please, write how this relationship started, 
how it developed and how you perceive this relationship now. These narrations were assessed by three coders (psychology students taking part in a course of narrative psychology) who were trained in methods on the following three dimensions - narrative coherence, emotional tone, and relation to self (see below). Narration was also assessed by one expert (second Author) who was the supervisor during the aforementioned course. For each dimension the mean of ratings from the pair of coders (supervisor and one of students) with the highest agreement (Krippendorff's $\alpha$ ) was used in analyses.

Narrative coherence. An analysis of narrative coherence based on operationalization by Baerger and McAdams (1999) was used in terms of: orientation, structure, affect, and integration. Orientation refers to locating characters and events in a specific context (temporal, social, personal). Structure is related to the chronological order of the story, which is oriented on a goal. Affect refers to the level of clarity and comprehensibility of emotions expressed in the story. Finally, integration is related to the tendency of the author to link the story with broader themes about their life or identity, as is considered a sign of autobiographical reasoning. These four aspects were assessed on 5-point scale ranging from 0 (no coherence) to 4 (high coherence). The coder agreements (Krippendorff's $\alpha$ ) were as follows: 72 for an orientation, .89 for a structure, .49 for an affect, and .89 for an integration. The low reliability of the affect dimension indicates the need for cautious interpretation.

Emotional tone. This was assessed using a pre-existing coding scheme (McAdams, 2001) and a 5-point scale ranging from 0 (very pessimistic emotional tone of the story) to 4 (very optimistic emotional tone of the story). The agreement between coders was acceptable (Krippendorff's $\alpha=.78$ ).

Relation to self. This coding dimension refers to how the written story was linked with the self, based on the autobiographical reasoning processes (Habermas, Bluck, 2000; Habermas, Köber, 2015). A linear system (0-3 points) proposed by McLean and Pratt (2006) was used to code stories: 0 - experiences have not been linked to self, 1 -experiences are linked with self but without the sense of any change caused by this experience, 2 - experiences are linked to self and some learning or lessons were detailed without extending beyond the original experience, 3 - experiences were linked to the self and learning or change occurred which extended beyond the specific experience and demonstrated that broader insight was gained about oneself. The rating coder agreement was acceptable (Krippendorff's $\alpha=.82$ ).

Length. This was assessed by the counting number of words for each story. The narratives about important relationship ranged in length from 7 to 281 words, with an average length of 119 
words $(S D=65.1)$. Length of narratives did not differ by gender $(t=1.67 ; p=.10)$, but was negatively correlated with age $(r=-.43 ; p<.001)$.

\section{Results}

Stronger awareness of narrative identity was weakly to moderately related to higher frequency of thinking and talking about life (see Table 2.). All subscales of the ANIQ were positively correlated with meaning in life, with the exception of temporal coherence and presence of meaning in life. Contrary to expectations, awareness of narrative identity was not related to self-esteem. Only thematic coherence was weakly positively correlated with higher self-esteem.

Turning to analyses of the written narratives of relational experiences, producing more elaborated and structured narrations referring to higher level of integrating experience with a self was positively correlated with being more aware of using a life story to build own identity and with perceiving thematic coherence between own experience. Perceiving temporal or causal coherence in own experience was not correlated with characteristics of narrations about relational experiences. Positive correlations were observed between awareness of narrative identity and most aspects of self-narrative inclination, except cultural heritage, however these were generally weak in strength. There was also a significant positive correlation between length (number of words) of self-narrations and all aspects of the awareness and perceived coherence of narrative identity except for causal coherence. These results are mostly in line with our hypothesis. However, stronger correlations were predicted.

\section{Table 2.}

Spearman Correlations Between Awareness of Narrative Identity and Variables Across All Studies.

\begin{tabular}{lccccc}
\hline & $\begin{array}{c}\text { ANIQ } \\
\text { Total }\end{array}$ & $\begin{array}{c}\text { ANIQ } \\
\text { Awareness }\end{array}$ & $\begin{array}{c}\text { ANIQ } \\
\text { Temporal } \\
\text { Coherence }\end{array}$ & $\begin{array}{c}\text { ANIQ } \\
\text { Causal } \\
\text { Coherence }\end{array}$ & $\begin{array}{c}\text { ANIQ } \\
\text { Chematic } \\
\text { Coherence }\end{array}$ \\
\hline Thinking about Life & $.33^{* * *}$ & $.36^{* * *}$ & $.23^{* * *}$ & .11 & $.27 * * *$ \\
Talking about Life & $.36^{* * *}$ & $.32^{* * *}$ & $.21^{* * *}$ & $.14^{*}$ & $.30^{* * *}$ \\
IAN Total & $.21^{* * *}$ & $.14^{*}$ & $.16^{*}$ & $.14^{*}$ & $.20^{* *}$ \\
IAN Recounting & $.17^{* *}$ & .11 & $.14^{*}$ & $.12^{*}$ & $.13^{*}$ \\
IAN Distancing & $.21^{* * *}$ & $.15^{*}$ & $.14^{*}$ & $.14^{*}$ & $.24 * * *$ \\
IAN Cultural heritage & .14 & .09 & $.15^{*}$ & .09 & .10
\end{tabular}




\begin{tabular}{|c|c|c|c|c|c|}
\hline MLQ Presence & $.26 * * *$ & $.21 * * *$ & .10 & $.22 * * *$ & $.29 * * *$ \\
\hline MLQ Search & $.33 * * *$ & $.24 * * *$ & $.24 * * *$ & $.21 * * *$ & $.33 * * *$ \\
\hline SES & .10 & -.01 & .10 & .10 & $.13^{*}$ \\
\hline \multicolumn{6}{|c|}{ Study 1 (N=71; Written Narrative Task) } \\
\hline $\mathrm{COH}$ Orientation & .18 & $.24^{*}$ & .23 & -.17 & .20 \\
\hline $\mathrm{COH}$ Structure & .17 & $.27 *$ & .19 & -.17 & .16 \\
\hline $\mathrm{COH}$ Affect & .18 & $.31 * *$ & .19 & -.06 & .15 \\
\hline $\mathrm{COH}$ Integration & $.28 *$ & $.28 *$ & .18 & .01 & $.26^{*}$ \\
\hline Emotional tone & .03 & .08 & -.07 & .02 & -.03 \\
\hline Integration with self & $.28^{*}$ & $.25 *$ & .15 & -.01 & $.33 * *$ \\
\hline Length (Productivity) & $.24 * *$ & $.31 * *$ & $.25^{*}$ & -.17 & $.28 *$ \\
\hline \multicolumn{6}{|c|}{ Study $2(N=424)$} \\
\hline RRQ Reflection & $.23 * * *$ & $.31 * * *$ & .02 & $.17 * * *$ & $.25 * * *$ \\
\hline RRQ Rumination & .07 & $.24 * * *$ & $-.11 *$ & .00 & $.12^{*}$ \\
\hline IAN Total & $.41 * * *$ & $.41 * * *$ & $.19 * * *$ & $.34 * * *$ & $.38 * * *$ \\
\hline IAN Recounting & $.23 * * *$ & $.22 * * *$ & $.14 * * *$ & $.16^{* * *}$ & $.21 * * *$ \\
\hline IAN Distancing & $.45 * * *$ & $.47 * * *$ & $.16^{* * *}$ & $.40 * * *$ & $.43^{* * *}$ \\
\hline IAN Cultural heritage & $.30 * * *$ & $.31 * * *$ & $.15^{* *}$ & $.26 * * *$ & $.26^{* * *}$ \\
\hline \multicolumn{6}{|c|}{ Study $3(N=162)$} \\
\hline PTGI Total & $.36 * * *$ & $.25 * *$ & $.26^{* *}$ & $.38 * * *$ & $.31 * * *$ \\
\hline PTGI Relating to others & $.25^{* *}$ & $.19 *$ & $.17 *$ & $.28 * * *$ & $.24 * *$ \\
\hline PTGI Self-perception & $.36 * * *$ & $.24 * *$ & $.24 * *$ & $.39 * * *$ & $.32 * * *$ \\
\hline $\begin{array}{l}\text { PTGI Appreciation of } \\
\text { Life }\end{array}$ & $.36 * * *$ & $.25^{* *}$ & $.29 * * *$ & $.34 * * *$ & $.29 * * *$ \\
\hline PTGI Spiritual Change & $.30 * * *$ & $.26 * * *$ & $.28 * * *$ & $.25 * *$ & $.22 * *$ \\
\hline
\end{tabular}

Note: $* * * p<.001 ; * * p<.01 ; * p<.05$

IAN - Self-Narrative Inclination Questionnaire; MLQ - Meaning in life Questionnaire; SES - Self Esteem Scale; PRQ - Rumination-Reflection Questionnaire; PTGI - Post-Traumatic Growth Inventory, $\mathrm{COH}$ - Narrative coherence.

Study 2 - Replicating Findings on Self-Narrative Inclination and Extending to Rumination and Reflection

\section{Materials and methods}

Participants and procedure

The study included 424 participants (recruited via social media and advertisements in the academic sites), from the general population (see Table 1 for demographic details) who 
gave informed consent to take part in a larger online remunerated scientific study with five daily measurements. The results presented here were obtained during the baseline measurement.

\section{Measures}

Awareness of Narrative Identity (see Study 1).

\section{Self-narrative Inclination (see Study 1).}

Rumination and Reflection. The Rumination-Reflection Questionnaire (RRQ) (Trapnell, \& Campbell 1999; Polish adaptation: Radoń, 2014) - consists of 24 items divided into two scales - rumination (12 items), and reflection (12 items). The subscale 'rumination' refers to negative aspect of repetitive thinking about the past, the present, and the future (maladaptive thoughts, evaluations, and emotions). The subscale 'reflection' refers to positive aspects of thinking about one's life related to gaining insight and a new perspective on one's experiences. Participants respond on each item using 5-point scales ranging from I completely disagree (1) to I completely agree (5). Higher scores indicate higher intensity of rumination, and/ or reflection. Both subscales demonstrate good internal reliability with Cronbach's $\alpha=.83$ for the 'rumination' subscale, and .81 for the 'reflection' subscale.

\section{Results}

In line with our research hypothesis, stronger awareness of narrative identity was positively correlated to higher reflexivity. Surprisingly, it was also positively correlated to rumination. Associations with self-narrative inclination were replicated, but overall were somewhat stronger and more consistent with awareness of narrative identity relative to Study 1, particular with overall awareness of narrative identity. This indicates that a higher inclination for taking a third-person perspective on one's life, recounting autobiographical events in a story, and making use of cultural heritage in those processes are related to being more aware of developing the story about own life.

\section{Study 3 - Awareness of Narrative Identity and Post-Traumatic Growth}

\section{Materials and methods}

\section{Participants and procedure}

The study included 162 participants recruited online with social media from a general population (see Table 1 for demographic details) who self-identified as having experienced trauma in their life. The Posttraumatic Growth Inventory (PTGI, Tedeschi \& Calhoun, 1996; 
Polish adaptation: Ogińska-Bulik \& Juczyński, 2010) was used to assess the time of the trauma relative to the present day and the type of trauma from a check-list. In our sample, we recruited participants with traumatic experiences, with 29 (17.9\%) having experienced trauma between a few months and a year before the study, 24 (14.8\%) between 1-2 years, 46 (28.4\%) between 2-5 years, and 63 subjects (38.9\%) more than five years. Participants most frequently identified as their trauma the loss of a loved one $(n=55,34.0 \%)$, a loss other than that indicated in the questionnaire $(36,22.2 \%)$, financial difficulties $(15,9.3 \%)$, and disaster $(n=14,8.6 \%)$. Chronic or acute illness, career change, relocation, violent or abusive crime, change in family responsibility, divorce, retirement, disability and job loss collectively represented $27.0 \%$ of the traumas identified. Participants gave informed consent to take part in the online nonremunerated scientific study. The majority of subjects had not received psychological help in the past (63.6\%), and the remaining had used consultation $(25.3 \%)$, individual psychotherapy (16.0\%), group psychotherapy (3.1\%) and support groups $(5.6 \%)$.

\section{Measures}

\section{Awareness of Narrative Identity (see Study 1).}

Posttraumatic growth. Posttraumatic growth refers to change to a person based on the trauma experienced, which leads to higher functioning, better well-being, and greater life awareness (Tedschi \& Calhoun, 2007). The Posttraumatic Growth Inventory (PTGI; Tedeschi \& Calhoun, 1996; Polish adaptation: Ogińska-Bulik \& Juczyński, 2010) consists of 21 items assessing four aspects of change under the influence of the traumatic experience: changes in self-perception (9 items), changes in relating with others ( 7 items), appreciation of life (3 items), and spiritual change ( 2 items). Participants were asked to indicate the degree to which the changes occurred in their life. Responses were marked on a 6-point Likert-type scale, ranging from 0 (I have not experienced this change due to the crisis) to 5 (I have experienced this change to a vast extent). Higher scores, including of a total score, indicate more positive changes resulting from the experienced trauma. In the present sample, the reliability of Cronbach's $\alpha$ was as follows: Changes in self-perception .91; Changes in relations to others .87; Appreciation of life .80; Spiritual changes .65, and .94 for the total score.

\section{Results}

Results are presented in Table 2. In a fairly uniform manner, a stronger awareness of narrative identity was positively correlated to all aspects of post-traumatic growth. The magnitude of those correlations varied from weak to moderate. 


\section{GENERAL DISCUSSION}

The objective of this series of studies was to examine relations between awareness of narrative identity, various aspects of narrative identity, and meaning-making. Our results suggest that awareness of narrative identity is related to the tendency to think and talk about one's own life. Weak to moderate associations were found between ANIQ variables and meaning in life, replicating previous findings (Hallford, \& Mellor, 2015; Sevim, \& Otram, 2021) that higher awareness of narrative identity and higher global coherence of autobiographical memories is associated with stronger sense of meaning in life, and also a searching for meaning in life. This is consistent with reasoning by Bauer et al. (2008) that awareness of developing narrations about own life may reflect higher integration of life experiences, and emergence of a sense of meaning.

There was little evidence for the association between awareness of narrative identity and self-esteem. It is difficult to explain this result. It is contrary to previous findings (Hallford, \& Mellor, 2015; Sevim, \& Otram, 2021) using the ANIQ, and research showing positive associations between the cohesion of life stories and self-esteem (Chen et. al., 2012; McLean, \& Breen, 2009; McLean et al., 2010). These differences may point to important cultural factors. For example, previous work using the ANIQ (Hallford \& Mellor, 2015) was conducted in predominantly white Anglo-Saxon culture, often considered as more 'positive' and optimistic than other cultures (Chang, 1996). The emotional climate of self-narration in building identity might be different among these countries, leading to stronger associations between life stories and self-esteem. That is, if life stories are more positively-valanced, then Anglo-Saxons may benefit more from being aware that their experiences are represented as a story about their self-identity. Future cross-cultural research could establish whether there are differences in the emotional tone of life stories and whether these cultural differences moderate how the ANIQ correlates with psychological resources such as self-esteem.

An important finding in this study was that awareness of narrative identity was positively correlated with written narrative characteristics, including orientation, structure, and integration. By replicating these findings from Hallford and Mellor (2015), there are now two separate studies showing concordance between self-report of one's perceptions of having life stories and their relevance to one' self-identity, and the coded coherence of specific narratives about their lives. This supports the idea that an abstracted sense of a coherent life story is related to coherence in specific recounting of life experiences. Therefore, people can self-report a global awareness of a narrated self that corresponds with specific stories. Although this study 
cannot provide infer causality, it does provide some support for the idea that increased coherence on the level of specific narratives might facilitate their integration into broader life stories, i.e., 'narrative identity processing' (Pals, 2006a, 2006b). Alternatively, this correlation might reflect an underlying tendency for meaning making of one's experiences, at levels of specific events and broader life stories. The correlations between specific global coherence subscales on the ANIQ and coded coherence in narratives were in the expected directions, but non-significant. However, these magnitudes were not strikingly different from previous findings (Hallford \& Mellor, 2015), and there was low power to detect statistical significance in this sample. Consistent with previous work, the awareness subscale had stronger correlations with coded coherence relative to the global coherence subscales. This suggests that awareness of life stories may be a more reliable predictor of the ability to provide coherent narratives of specific experiences relative to a person's perception of how coherent their memories are on specific dimensions.

The tendency to express one's own experiences in a narrative manner or narrative reporting (self-narrative inclination) is only weakly to moderately associated with narrative identify awareness. These findings suggest that developing life stories (narrative identity), being aware of them (awareness of narrative identity), and narrations about particular events or experiences may be largely separable constructs. Hence, it could conceivably be hypothesized that they are subject to different rules and influence of different factors (see also Soroko, \& Majchrzak, 2020 for similar results). It is possible that narrations about events precede development of the life story. According to Bluck and Habermas (2000), only memories that are linked to self through their emotional or motivational significance over one's life are truly autobiographical, and the life story schema could be a framework for the process of life story development.

Another important finding of this study is that a stronger awareness of narrative identity was positively related to a stronger post-traumatic growth. This association is consistent with findings suggesting that developing narrative identity leads to a sense of purpose, meaning, and unity across time and situation (Adler, 2012; McAdams, \& McLean, 2013). It seems that people who are more conscious about drawing on their life story to understand the kind of person they are, may also be stronger motivated to narratively processing their negative past experiences through autobiographical reasoning to help how they cope with trauma. Further studies should investigate how awareness of narrative identity is directly related to autobiographical reasoning, 
and how it moderates the effectiveness of narrative interventions aimed to coping with negative past events.

\section{Limitations and Further Studies}

A few important limitations need to be considered. First, these results may not be transferable to countries other than Poland. Cross-national comparative studies considering cultural factors in the role of narrative activity for psychological well-being should be done in the future. Second, the correlational nature of these studies does not allow us to draw conclusions regarding causal relationships. Rather, these calls for longitudinal or experimental studies on the role of awareness of narrative identity for meaning-making and mental health more broadly. Third, more research is needed to better understand difference between various aspects of narrative activity and their role in relation to psychological well-being, self-esteem, emotional functioning, and meaning in life. Comparing the relationship between awareness of narrative identity and properties of narratives about a single event and a whole 'life story' may shed light on the mutual relations between these various aspects involved in developing the narrative identity. Finally, further studies could integrate our findings and explore the role of all aspects of narrative identity in terms of meaning-making, and mental health. Regression, or Structural Equation Model could be useful here.

\section{Conclusions}

The goal of the presented studies was to investigate associations between awareness of narrative identity and other aspects of narrative-activity (self-narrative inclination, frequency of thinking and talking about own life, and characteristics of self-narrations), self-esteem, meaning in life, and post-traumatic growth. Our findings suggest that general awareness of narrative identity is something different than self-narrative inclination, just thinking about one's own life, or producing 'good stories'. However, these various aspects of narrative activity may be somehow correlated., It may be useful to consider as a specific dimension when studying the role of narratives and narrative identity in psychological well-being These findings also support the adaptive role of awareness of narrative identity by confirming its' relations with meaning in life, post-traumatic growth, and self-relevance. Our findings are partially in line with the previous research on that topic, and partially inconsistent with them. These relationships may be moderated by a cultural context. To conclude, being aware of developing 
narrative identity basing on the life story may be adaptive in terms of meaning in life and coping with trauma.

\section{ACKNOWLEDGEMENT}

We would like to thank Aleksandra Berndt for her contribution to collecting data for Study 3 and the team of researchers involved in project „Do self-narrative diary interventions during COVID-19 pandemic improve mental health?” (Michał Dolczewski, Paweł Kleka, Maciej Borzyszkowski, Apolonia Borzęcka), who enabled us to collect data for Study 2. We would also like to thank Jorge Ricarte whose comments on the previous version of the text were very helpful.

\section{FUNDING}

The collection of data for Study 2 was a part of a project „Do self-narrative diary interventions during COVID-19 pandemic improve mental health?" funded by the Rector of Adam Mickiewicz University within the competition "Research on COVID-19" (01.11.202030.04.2021).

\section{DECLARATION OF INTEREST STATEMENT}

The authors declare that they have no conflict of interest. 


\section{REFERENCES}

Adler, J. M. (2012). Living into the story: Agency and coherence in a longitudinal study of narrative identity development and mental health over the course of psychotherapy. Journal of Personality and Social Psychology, 102, 2, 367-389.

Adler, J. M., Chin, E. D., Kolisetty, A. P., \& Oltmanns, T. F. (2012). The distinguishing characteristics of narrative identity in adults with features of Borderline Personality Disorder: An empirical investigation. Journal of Personality Disorders, 26, 4, 498-512.

Adler, J. M., Skalina, L. M., \& McAdams, D. P. (2008). The narrative reconstruction of psychotherapy and psychological health. Psychotherapy Research, 18, 6, 719-734.

Baerger, D. R., \& McAdams, D. P. (1999). Life story coherence and its relation to psychological well-being. Narrative Inquiry, 9, 69-96.

Blagov, P., Berry, M., Oost, K.M., \& Singer, J.A. (2013). Self-defining memories, scripts, and the life story: narrative identity in personality and psychotherapy. Journal of personality, $81,6,569-82$.

Bluck, S., \& Habermas, T. (2000). The life story schema. Motivation and emotion, 24(2), 121147.

Chang, E. C. (1996). Cultural differences in optimism, pessimism, and coping: Predictors of subsequent adjustment in Asian American and Caucasian American college students. Journal of Counseling Psychology, 43(1), 113.

Chen, Y., McAnally, H. M., Wang, Q., \& Reese, E. (2012). The coherence of critical event narratives and adolescents' psychological functioning. Memory, 20, 667-681.

Habermas, T., \& Bluck, S. (2000). Getting a life: The emergence of the life story in adolescence. Psychological Bulletin, 126, 5, 748-769.

Habermas, T., \& Köber, C. (2015). Autobiographical reasoning in life narratives buffers the effect of biographical disruptions on the sense of self-continuity. Memory, 23, 5, 664-74

Hallford, D. J., \& Mellor, D. (2015). Development and validation of the Awareness of Narrative Identity Questionnaire (ANIQ). Assessment, 24, 3, 399 - 413.

Hallford, D. J., \& Mellor, D. (2016). Brief reminiscence activities improve state well-being and self-concept in young adults: a randomised controlled experiment. Memory, 24(10), 1311-1320. https://doi.org/10.1080/09658211.2015.1103875

Hallford, D. J., Ricarte, J. J., \& Hermans, D. (2021). Perceived Autobiographical Coherence Predicts Depressive Symptoms Over Time Through Positive Self-Concept. Frontiers in Psychology, 12, doi:10.3389/fpsyg.2021.625429

Hallford, D. J., Hardgrove, S., Sanam, M., Oliveira, S., Pilon, M., \& Duran, T. (2021). Remembering for Resilience: Brief Cognitive-Reminiscence Therapy Improves Psychological Resources and Mental Well-Being in Young Adults. Preprint. https://doi.org/10.31234/osf.io/u9wbr

Kossakowska, M., Kwiatek, P., Stefaniak, T. (2013). Sens w życiu. Polska wersja kwestionariusza

MLQ (Meaning in Life Questionnaire). Psychologia Jakości Życia, 12, 2, 111-131.

Łaguna, M., Lachowicz-Tabaczek, K., Dzwonkowska, I. (2007). Skala samooceny SES Morrisa Rosenberga - polska adaptacja metody. Psychologia Społeczna, 4, 164-176.

McAdams, D. P. (2001). The psychology of Life-Story. Review of General Psychology, 5, 100-122. 
McAdams, D. P. (2006). The role of narrative in personality psychology today. Narrative Inquiry, 16, 1, 11-18.

McAdams, D. P., \& McLean, K. C. (2013). Narrative Identity. Current Directions in Psychological Science, 22(3), 233-238. https://doi.org/10.1177/0963721413475622

McLean, K. C., \& Breen, A. V. (2009). Processes and content of narrative identity development in adolescence: Gender and well-being. Developmental Psychology, 45, 702-710.

McLean, K. C., Breen, A. V., \& Fournier, M. A. (2010). Constructing the self in early, middle and late adolescent boys: Narrative identity, individuation, and wellbeing. Journal of Research on Adolescence, 20, 166-187.

McLean, K. C., \& Pratt, M. W. (2006). Life's Little (and Big) Lessons: Identity Statuses and Meaning-Making in the Turning Point Narratives of Emerging Adults. Developmental Psychology, 42, 4, 714-722.

Mitchell, C., Reese, E., Salmon, K., \& Jose, P. (2020). Narrative coherence, psychopathology, and wellbeing: Concurrent and longitudinal findings in a mid-adolescent sample. Journal of Adolescence, 79. https://doi.org/10.1016/j.adolescence.2019.12.003

Niederhoffer, K.G., \& Pennebaker, J.W. (2009). Sharing one's story: On the benefits of writing or talking about emotional experience, In: S.J. Lopez, \& C.R. Snyder (eds.) Oxford Handbook of Positive Psychology (p. 621-632). New York: Oxford University Press.

Oleś, P. K. (2004). Konstruowanie autonarracji - refleksja teoretyczna. W: E. Dryll, A. Cierka (red.), Narracja. Koncepcje $i$ badania psychologiczne (s. 197-206). Warszawa: Wydawnictwo Instytutu Psychologii PAN.

Pals, J. L. (2006a). Authoring a second chance in life: Emotion and transformational processing within narrative identity. Research in Human Development, 3 (2-3), 101-120.

Pals, J. L. (2006b). The narrative identity processing of difficult life experiences: Pathways of personality development and positive self-transformation in adulthood. Journal of Personality, 74, 1080-1109.

Pasupathi, M., \& Mansour, E. (2006). Adult age differences in autobiographical reasoning in narratives. Developmental Psychology, 42, 5, 798-808.

Radoń, S. (2014). Kwestionariusz Ruminacji-Refleksyjnosci (Polska adaptacja the Rumination-Reflection Scale)[Rumination-Reflection Questionnaire (Polish adaptation of the RRQ)]. Psychoterapia, 2, 61-72.

Rosenberg, M. (1965). Society and the adolescent self-image. Princeton, NJ: Princeton University Press.

Sevim, E., \& Otrar, M. (2021). The Validity and Reliability of Turkish Version of Awareness of Narrative Identity Questionnaire (ANIQ). Kastamonu Ĕgitim Dergisi, 29(3), 769-777. https://doi.org/10.24106/kefdergi.882179

Singer, J. A., \& Bluck, S. (2001). New perspectives on autobiographical memory: The integration of narrative processing and autobiographical reasoning. Review of General Psychology, 5, 2, 91-99. 
Soroko, E. (2013). Kwestionariusz Inklinacji Autonarracyjnej (IAN-R) - pomiar skłonności do narracyjnego opracowywania i relacjonowania doświadczenia. Studia Psychologiczne, $51,5-18$.

Soroko, E. (2014). Aktywność autonarracyjna osób z różnym poziomem organizacji osobowości. Opowieści o bliskich związach. Poznań: Wydawnictwo Naukowe UAM.

Soroko, E., Janowicz, K., Frąckowiak, A., \& Siatka, A. (2019). Polska wersja kwestionariusza do badania świadomości tożsamości narracyjnej (Awareness of Narrative Identity Questionnaire-PL, ANIQ-PL). Polskie Forum Psychologiczne, 24 (4), 477-497.

Soroko, E., Majchrzak, P. (2020). Studies on self-narrative activity: The self-report and verbal expression. Journal of Constructivist Psychology, DOI: 10.1080/10720537.2020.1739581.

Steger, M.F., Frazier, P., Oishi, S., Kaler, M. (2006). The Meaning in Life Questionnaire: Assessing the presence of and search for meaning in life. Journal of Counseling Psychology, 53, 80-93.

Suchanska, A., \& Ligocka, M. (2011). Narrative Inclination vs Self-Complexity and Identity. Studia Psychologiczne, 49(2), 19.

Trapnell, P. D., \& Campbell, J. D. (1999). Private self-consciousness and the five-factor model of personality: distinguishing rumination from reflection. Journal of personality and social psychology, 76(2), 284. 